\title{
Investigating telecollaborative genres: analysis of teletandem oral sessions communicative purpose through learners' diaries
}

DOI: http://dx.doi.org/10.21165/el.v50i3.2981

\section{Laura Rampazzo ${ }^{1}$}

\begin{abstract}
This paper aims to investigate the communicative purpose of a telecollaborative genre, namely the initial teletandem oral session (iTOS), the first virtual encounter between learners who participate in the Teletandem Brasil project. Although telecollaborative genres are still underexplored, studies have been advancing in observing the development of a community, and in identifying the patterns of action that are effective. Through the analysis of 17 learners' diaries, available at Multimodal Teletandem Corpus, the present study examines students' stance on the communicative purpose of the genre. Results suggest that learners recognize the purpose of iTOS to be to get to know their partners and find common ground, and indicate that both learners and researchers have similar views on what the communicative purpose of the genre iTOS is.
\end{abstract}

Keywords: telecollaboration; genres; Multimodal Teletandem Corpus (MulTeC).

1 Instituto Federal de São Paulo (IFSP), Barretos, São Paulo, Brasil; laura.rampazzo@ifsp.edu.br; https://orcid.org/0000-0002-4736-9900 


\section{Investigando gêneros telecolaborativos: análise do propósito comunicativo das sessões orais de teletandem através de diários de aprendizagem}

Resumo: O objetivo deste trabalho é investigar o propósito comunicativo do gênero Sessão Oral de Teletandem inicial (SOTi), o primeiro encontro virtual entre estudantes no projeto Teletandem Brasil. Embora os gêneros telecolaborativos sejam ainda pouco explorados, estudos vêm avançando ao observarem a formação de uma comunidade e ao identificarem os padrões de ação que são eficazes. Por meio da análise de 17 diários de aprendizagem, disponíveis no Multimodal Teletandem Corpus, o presente estudo examina o ponto de vista dos aprendizes quanto ao propósito comunicativo do gênero. Os resultados sugerem que os estudantes reconhecem que o propósito da SOTi é se conhecerem e encontrarem pontos em comum, além de indicarem que aprendizes e pesquisadores têm entendimentos similares quanto ao seu propósito comunicativo.

Palavras-chave: telecolaboração; gêneros; Multimodal Teletandem Corpus (MulTeC).

\section{Introduction}

Telecollaboration or virtual exchange are terms commonly used to refer to practices that involve geographically distant learners who engage in (a)synchronous communication through online tools and work towards a common goal. According to Dooly and Sadler (2020, p. 4-5), it is "an increasingly popular means of engaging pre-service teachers in cross-cultural, international peer reflection and dialogic learning".

Indeed, in Brazil, for over 16 years now, the project Teletandem Brasil (TELLES, 2006, 2015) has been promoting intercultural communication between students, many of whom are pre-service teachers. Learners form dyads and help one another in learning their own language or language of proficiency. Based on tandem principles of separation of languages, autonomy and reciprocity (BRAMMERTS, 1996; VASSALLO; TELLES, 2006)2, teletandem practice may be institutionalized and integrated to the activities promoted in language classes in university settings. When that is the case, it is named institutional integrated teletandem (iiTTD) (ARANHA; CAVALARI, 2014; CAVALARI; ARANHA, 2016).

iiTTD is a blended learning setting in which language professors in two institutions form a partnership and learners engage in weekly teletandem oral sessions (TOS) - the

2 Separation of languages principle establishes that each oral session should be divided in two equal parts, each for the practice of the languages of a partnership. Autonomy means that learners are autonomous enough to make decisions about their own learning process. The principle of reciprocity defines that learners should be invested in their partners' learning and alternate in the roles of learners of a target language and tutors of their own language or language of proficiency. 
synchronous encounters - for a period of time. Such sessions occur all at the same time during their language classes at an appropriate place, such as a teletandem lab (ARANHA; CAVALARI, 2014). According to Aranha and Cavalari (2014), joining iiTTD is mandatory, it involves other tasks and learners are assessed and graded on their participation.

Aranha (2014), who presents a discussion of one of the tasks in iiTTD - TOS -, shares the understanding that learners involved in teletandem form the Teletandem Community (TC) (SILVA, 2012; RAMPAZZO; ARANHA, 2019a), whose members work towards common goals through the use of genres - goal-directed communicative events that exhibit patterns in terms of structure, style, content and intended audience (SWALES, 1990; ASKEHAVE; SWALES, 2001). Aranha (2014) argues that the tasks that occur in iiTTD form a complex system of interrelated genres that are employed to fulfill the purposes of the members of the TC.

One of such genres is the initial teletandem oral session (iTOS), the first virtual and synchronous encounter. Aranha (2014), who first examined the rhetorical structure of iTOS first 15 minutes, suggests recurrence in iTOS samples indicate it is a genre. Later, Rampazzo (2017), and Rampazzo and Aranha (2018, 2019b) corroborate that the structure of the first 15 minutes remains very similar for different dyads.

Based on the rhetorical analysis of iTOS, the researchers suggest that the communicative purpose of iTOS is to establish the contact and sustain the partnership. However, studies have not yet considered learners' information on the communicative purpose of this genre. Given that they are also members of the TC and present their reflections about the oral sessions on the learners' diaries written after each oral session, the analysis of learners' first diaries may shed light on (one of) iTOS purposes, which may contribute to elucidate how members of TC work towards their goals. Diaries are also considered useful data for investigation both in telecollaborative environments (HELM, 2009) and in other educational settings (CURTIS; BAILEY, 2009) for they provide the researcher a way of identifying processes that are not easily accessible or open to investigation.

This paper presents the results of an investigation that intended to identify (one of) the communicative purpose(s) of iTOS and aims at answering the following question: What can learners' diaries of iTOS inform us about its communicative purpose?

\section{Literature review: genres and teletandem}

Research on teletandem has focused on eight thematic areas: learning in teletandem, culture, context description, teacher education, assessment, mediation, genres, and research databank, being genres still an underexplored topic (RAMPAZZO; CUNHA, 
$2021^{3}$ ). Despite only few publications concentrating on genres (SILVA, 2012; ARANHA, 2014; ARANHA; BRAGAGNOLLO, 2015; RAMPAZZO, 2017; RAMPAZZO; ARANHA, 2018, $2019 \mathrm{~b})$, studies have been advancing on investigating the ones involved in the practice as a community whose members share common goals (SILVA, 2012; RAMPAZZO; ARANHA, 2019a) and the characteristics of the genres that recur in the teletandem community (ARANHA, 2014; RAMPAZZO, 2017, 2021; RAMPAZZO; ARANHA, 2018, 2019b). Such studies help with identifying the patterns of action that are effective in this form of telecollaboration.

The basis for such studies is the genre theories that have traditionally supported the discussion of genres in the academia, New Rhetoric (MILLER, 1984; BAZERMAN, 1994, among others) and Genre Analysis (also known as socio-rhetorical studies in Brazil) (SWALES, 1990, 2004; BHATIA, 1993, among others). These theories propose that genres work as frames for social action, being referred to as typified responses to a given rhetorical situation. As similar responses to a situation, genre samples show recurrent patterns in terms of structure, style, content, and are used by members of a discourse community to accomplish their goals.

Swales (1990) theorizes about the concept of discourse community (DC), putting it at the center of his proposal for genre analysis. The author mentions that DCs are sociorhetorical networks that form so that individuals who have similar professional or recreational purposes can work together towards these goals. Over the years, Swales revisited this concept (SWALES, 1998, 2016), emphasizing the inextricable relationship between genres and communities, given that members of a DC share common goals, which are fulfilled through the use of the genres acquired or developed by the DC.

In Swales' (2016, p. 15-17) most recent account of the DC, he mentions that a DC (1) has a set of goals; (2) mechanisms of intercommunication among its members, some of which may integrate new technologies; (3) has participatory mechanisms for providing information and feedback; (4) uses a selection of genres; (5) has specific terminology; (6) has an explicit or implicit hierarchy that manages the processes of entry and advancement within the community; (7) develops a sense of 'silential' relations, an understanding that some things do not need to be said; (8) has a sense of its history and a value system.

Regarding the use of genres by the members of a DC, it should be noted that Swales' (2016) definition put emphasis on the fact that a community makes use of more than one genre, reinforcing an argument defended by the author in other publications: genres form complex networks, connecting to one another (SWALES, 1993, 2004, 2009; SWALES et al., 2000), each having (a) communicative purpose(s) that link(s) to the goals of the community.

3 The study considers published research articles only. Other themes and issues may have been examined on book chapters, Masters' thesis and PhD dissertations. 
The communicative purpose is also a significant concept to genre analysis for it offers a better understanding of a corpus of discourses, helping in determining whether they might have a genre status or not (ASKEHAVE; SWALES, 2001). Bhatia (1993), for instance, mentions that each genre represents a successful realization of a specific communicative purpose; in other words, genres are successful responses towards a goal employed by members of a DC.

Nevertheless, despite its relevance to genre analysis, Askehave and Swales (2001) draw attention to the fact that genres may be multi-purposeful and goals may be evasive and complex. They advocate for procedures of 'repurposing the genre', which consists of establishing a provisional communicative purpose of a genre for then redefining it after thorough research of the genre in its contexts, which includes observation of the DC. Swales (2004) also argues for procedures of repurposing the genre and adds that the analyst should observe the genre network as well.

The positioning that genres relate to one another to fulfill DC's goals, each having its own communicative purpose(s), is the rationale behind Aranha's (2014) proposal for discussing the tasks in the institutional integrated teletandem (iiTTD) modality as genres.

The occurrence of tasks in teletandem varies according to learners' needs, partnerships, and professors' decisions, but, as stated by Aranha and Leone (2017), teletandem practice generally displays a coherent and complex activity framework formed by two macrotasks: teletandem oral sessions and mediation sessions - when learners have the opportunity to reflect about the learning process under the guidance of their professors.

Aranha and Leone (2017) explain that macrotasks are supported by microtasks: each teletandem oral session, that is, each synchronous encounter; a tutorial meeting to get learners acquainted with the project; written tasks for the practice of the target language; learning diaries written after each oral session; and questionnaires - an initial one for establishing learning goals, and a final one for evaluating the experience.

Aranha (2014) proposes such tasks as genres for considering them as typified and recurrent actions shared by learners, who are members of TC (SILVA, 2012; RAMPAZZO; ARANHA, 2019a). The definition of TC, first proposed by Silva (2012) as an account for the learners who engage in the practice, was revisited by Rampazzo and Aranha (2019a) to describe not only the grouping of learners, but also other individuals involved: professors/ mediators and researchers.

TC is formed because members share similar interests, goals, knowledge, and practice, and its members are of different degrees: the learners, the professors/mediators, and the researchers (RAMPAZZO; ARANHA, 2019a). The different degrees also implicate a 
hierarchy among its members, and professors and researchers tend to be more expert members who try to communicate their traditions to new members, mostly the students, who may vary each semester. Rampazzo and Aranha (2019a) argue that TC members share mechanisms of virtual communication and develop a set of rules that govern their interactions, some of which are virtually held.

In addition, a characteristic of TC that is emphasized by the authors is the development of genres. According to Rampazzo and Aranha (2019a, p. 398), members of TC "develop genres in order to fulfill their purposes, which may or may not be the same for every member". In this quote, it is stressed not only that genres are used by TC to accomplish their goals, but also that members of different degrees may use the genres to serve diverse needs. On the level of each genre, then, multiple purposes may be identified.

Up to this moment, the task that has had part of its generic structure examined is the initial teletandem oral session (iTOS), a genre that connects to others in the realization of TC's goals.

Rampazzo and Aranha (2019b) identified that, for the first 15 minutes of iTOS, the discourse is organized in rhetorical argumentative parts, in which participants negotiate certain aspects, exchange information, mostly personal, and discuss the texts exchanged. Based on the conversation between learners and on the fact that they try to find common interests, the authors argue that iTOS communicative purpose is to establish contact and support the partnership.

Figure 1 pictures part of the system of genres that occur in iiTTD, the lines representing the genres networks, and the arrows the ones that happen in sequence. Depicted in the figure, the tutorial meeting is the moment in which professors explain the project and present what is expected of the learners, the tasks they need to carry out, and the due dates of such tasks. 
Figure 1. Part of iiTTD genre system

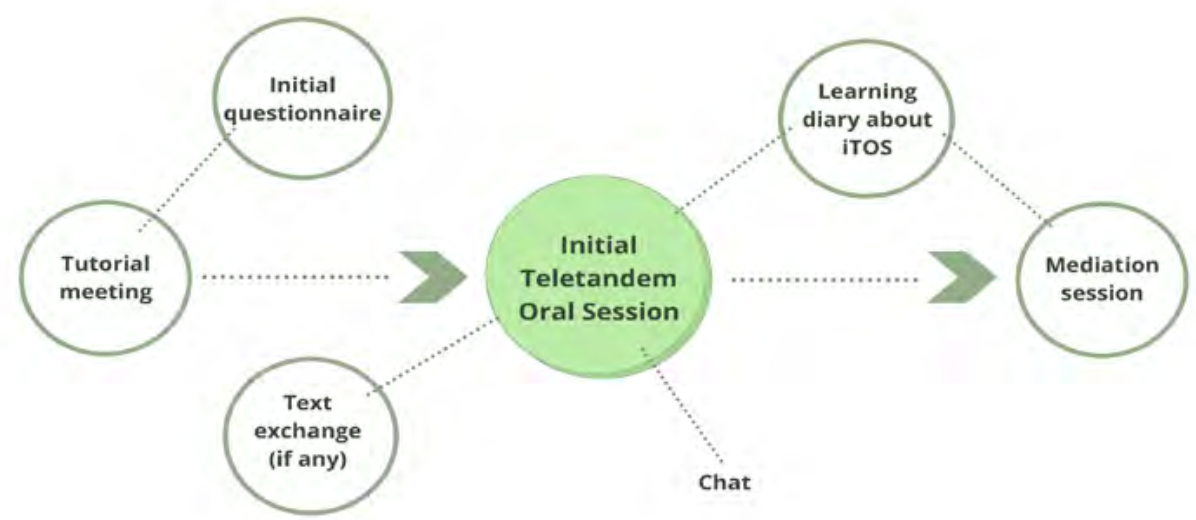

Source: The author, based on Rampazzo (2017, p. 126)

Generally, according to Cavalari and Aranha (2016), in the final minutes of the meeting, learners fill in the initial questionnaire, when they establish the learning goals for the project. Both the tutorial meeting and the initial questionnaire may impact iTOS in the sense that during the session learners need to be aware of the principles taught during the tutorial and the goals they determined in the questionnaire.

Depending on the arrangements between professors, students may be asked to exchange texts before the first virtual encounter and discuss them during the iTOS. After the oral session, learners should write a learner diary, intended to promote self-reflection as well as to serve as input for the mediation sessions.

According to Silva (2014), who investigated how writing in the diaries helps to promote learners' autonomy in teletandem, students receive instructions on how to write the selfreflection about their learning experience. The author points out that the diaries should include five areas: (i) the topics that emerged in the session; (ii) things the students learned; (iii) reflections about their learning goals; (iv) reflections about any conflicts during the sessions; (v) reflections about supporting each other's learning process (SILVA, 2014).

Diaries about learners' experience in teletandem should, then, be a combination of factual records and interpretations, which represents the ideal diary data, according to Curtis and Bailey (2009), who also propose that diaries "can provide us with data that may reveal aspects of the language learning or language teaching experience which are difficult, if not impossible, to attain by other means" (p. 79). Considering that factual records should also be included in learners' notes, it may be said that iTOS feeds the first diary, and 
the diary may elucidate students' understanding of the purpose of the iTOS as students should include information about what they did during the oral session.

\section{Methods}

Data for the research reported in this paper is available at Multimodal Teletandem Corpus (MulTeC) (ARANHA; LOPES, 2019). MulTeC is a multimodal corpus that includes files generated from Teletandem partnerships established between São Paulo State University (UNESP) in Brazil, São José do Rio Preto campus, and University of Georgia (UGA) in the United States in the years 2012 until 2015. According to Lopes (2019), and Aranha and Wigham (2020), the corpus includes 581 hours of teletandem oral sessions, 666 learning diaries from Brazilian learners, 91 initial questionnaires, 41 final questionnaires, 956 texts written by Brazilian students, and 355 chat registers from 282 participants, who consented to sharing their data for research. Data is organized in tree files, separated according to the modality, year, semester, and groups.

Data was randomly selected - the only criteria being that the first learning diaries were all from learners from the same group - and consists of 17 learners' diaries written by the Brazilian participants of an institutional integrated partnership that took place in September and October of 2015. Students in Brazil were first year undergraduates in Languages (Translation), and participants abroad were all enrolled in Portuguese class. The majority of Brazilians were in their late teens/early twenties and self-assessed themselves as intermediate learners of English based on the CEFR (table 1). No information about American learners' majors, age, or self-assessed proficiency level in the target language could be retrieved from the corpus.

Table 1. Information on the Brazilian participants

\begin{tabular}{|c|c|c|c|c|}
\hline File in MulTeC & Referred to as & $\begin{array}{c}\text { Self-assessed proficiency } \\
\text { level }\end{array}$ & Gender & Age \\
\hline 2015_I8F1_UGA3i_D1 & D-1 & B1 & Female & 19 \\
\hline 2015_18M2_UGA3i_D1 & D-2 & A2 & Male & 20 \\
\hline 2015_I8F3_UGA3i_D1 & D-3 & C1 & Female & 20 \\
\hline 2015_I8F4_UGA3i_D1 & D-4 & B2 & Female & 18 \\
\hline 2015_I8F5_UGA3i_D1 & D-5 & B1 & Female & 21 \\
\hline 2015_I8F6_UGA3i_D1 & D-6 & B2 & Female & 20 \\
\hline 2015_I8F7_UGA3i_D1 & D-7 & B1 & Female & 18 \\
\hline 2015_18M8_UGA3i_D1 & D-8 & B1 & Male & 19 \\
\hline 2015_I8F9_UGA3i_D1 & D-9 & B2 & Female & 18 \\
\hline
\end{tabular}




\begin{tabular}{|c|c|c|c|c|}
\hline 2015_I8M11_UGA3i_D1 & D-10 & B2 & Male & 20 \\
\hline 2015_I8M12_UGA3i_D1 & D-11 & B2 & Male & 18 \\
\hline 2015_I8F13_UGA3i_D1 & D-12 & x & Female & 42 \\
\hline 2015_I8F14_UGA3i_D1 & D-13 & B2 & Female & 18 \\
\hline 2015_I8F15_UGA3i_D1 & D-14 & B2 & Female & 24 \\
\hline 2015_I8F17_UGA3i_D1 & D-15 & B1 & Female & 19 \\
\hline 2015_I8F18_UGA3i_D1 & D-16 & B1 & Female & 18 \\
\hline 2015_I8F19_UGA3i_D1 & D-17 & B2 & Female & 20 \\
\hline
\end{tabular}

Source: The author, based on the information available on MulTeC (ARANHA; LOPES, 2019)

Besides participating in the oral sessions, learners responded to questionnaires and had two types of writing tasks for the practice of the target language: they exchanged introductory emails before iTOS and had two collaborative writing tasks, in which dyads wrote, together, a text in Portuguese and another one in English. According to information presented to learners in the tutorial, students were expected to get to know each other during iTOS and discuss/revise the emails exchanged. They were requested to write diaries after each session, and their first diaries compose the corpus for this study (table 2).

Table 2. Information on the data investigated

\begin{tabular}{|l|l|}
\hline Size & 1,962 words \\
\hline Number of texts & 17 \\
\hline Medium & Electronic (shared via Google Docs, and stored in txt format) \\
\hline Subject & $\begin{array}{l}\text { First learner diary - factual records and reflections about the initial } \\
\text { teletandem oral session }\end{array}$ \\
\hline Authorship & $\begin{array}{l}\text { Brazilian learners of English in their first year, majoring in Translation } \\
\text { studies. }\end{array}$ \\
\hline Language & Portuguese (mother tongue) or English (not corrected) \\
\hline Production date & September 9,2015 \\
\hline
\end{tabular}

Source: The author, based on the information available on MulTeC (ARANHA; LOPES, 2019)

As stated in the previous section, learners are given instructions on what is expected to be found in the diaries: topics that emerged in the session; things that they learned; reflections about learning goals; reflections about any conflicts; reflections about supporting each other's learning process. It is, then, expected that the diaries include a factual record of iTOS, that is, a part in which students report on what happened and what they talked about. Analysis procedures consisted of identifying the portions of the diaries in which learners 
comment on what they talked about during iTOS, given that such information relates to what members of the community recognize as the genre communicative purpose.

Table 3. Example of analysis procedures

\begin{tabular}{|c|c|c|c|}
\hline Diary & $\begin{array}{c}\text { Extracts that report on what learners talked about } \\
\text { during iToS }\end{array}$ & $\begin{array}{c}\text { Words } \\
\text { dedicated } \\
\text { to reporting } \\
\text { topics }\end{array}$ & $\begin{array}{c}\text { Information } \\
\text { that may be } \\
\text { gathered from } \\
\text { the extracts }\end{array}$ \\
\hline D-1 & Did not report. & $x$ & $x$ \\
\hline D-2 & $\begin{array}{c}\text { "My partner asked me some questions and did } \\
\text { the same, so we both practiced a lot our learning } \\
\text { languages. We also learned about the university of } \\
\text { each of us". }\end{array}$ & 29 & $\begin{array}{c}\text { Learners } \\
\text { exchanged } \\
\text { information } \\
\text { about their } \\
\text { academic } \\
\text { lives. }\end{array}$ \\
\hline D-3 & $\begin{array}{r}\text { "(...) I had the chance to get to know a little about } \\
\text { U0M3 (...)" }\end{array}$ & 12 & $\begin{array}{c}\text { Learners } \\
\text { exchanged } \\
\text { personal } \\
\text { information }\end{array}$ \\
\hline
\end{tabular}

Source: The Author

The extracts from the diaries were compiled into a table and interpreted by the analyst in order to identify recurrent ideas (table 3) that could inform learners' understanding of the communicative purpose of iTOS. There is also the quantification of words in each diary in order to determine how much of the diary was dedicated to informing the topics discussed during iTOS. The tool used for it was Word Count. Results and discussion are presented in the next section.

\section{Results and discussion}

The investigation of the first learners' diaries indicates that Brazilian learners generally report on what was discussed during iTOS - out of 17, 14 present a short report. The diaries themselves tend to be very concise - an average of 115 words per diary - and so is the account of what happened in the oral session - an average of 21 words per diary, the longest one having 70 words, and the shortest, 12. Most of the journals are written in English, Brazilian learners' target language, but a few (4) are written in Portuguese.

Overall, all learners who report on what they talked about during iTOS state that they exchanged personal information, talked about themselves and/or their academic lives. This suggests that they understand one of the purposes of iTOS is to focus on personal information exchange, as the extract 1, from D-3, demonstrates: 
Table 4. Excerpt 1

I had the chance to get to know a little about UOM3.

Source: MulTeC (ARANHA; LOPES, 2019)

Although the student in D-3 does not present any details of what she and her partner talked about, she reports that iTOS was an opportunity for her to learn more about the partner assigned to her. Similarly, the learner in D-10 also presents an outline of the topics in iTOS:

Table 5. Excerpt 2

We asked things in general to get to know each other more.

(D-10)

Source: MulTeC (ARANHA; LOPES, 2019)

Differently from excerpt 1 , in 2 , the student stresses that not only he got to know his partner, but that personal information about himself was discussed as well. In fact, the use of expressions such as "get to know" or "conhecer/aprender" and their variations are common and tend to be associated with getting information about themselves: "get to know about U0M3" (D-3), "we met ourselves" (D-5), "get to know each other" (D-10), "aprender algumas coisas sobre a parceira" (D-13), "learn about each other" (D-15).

Some learners are more specific when commenting on what they talked about, such as the learner in D-9:

Table 6. Excerpt 3

I asked questions about daily life, such as how american college life worked and what they had for breakfast, because I need to break down some stereotypes I hold about USA's culture. (...) My partner has mexican heritage, so I asked if it helped her in any way during her Portuguese lessons. (...) I told her a bit more about my personal life, because my e-mail felt pretty shy after reading hers.

Source: MulTeC (ARANHA; LOPES, 2019)

In D-9, the learner specifies that the questions revolved around their personal lives, mostly their routines, academic lives and studies. The learner also mentions the email exchange task to explain why she felt the need to increase the amount of time talking about herself, given that her partner had shared a lot in the introductory email sent. 
The reference to the email task appears in other diaries as well (D-6, D-7 and D-8), and it is related to the topic of personal information as, according to instructions given to students ${ }^{4}$, learners were supposed to write introductory emails in which they would introduce themselves:

Table 7. Excerpt 4

At the first interaction we talked about our emails. UOM8 asked me some things about Brazil because he is coming to Minas Gerais next year. I asked him some things about him, like his age, his course, etc.

(D-8)

Source: MulTeC (ARANHA; LOPES, 2019)

The learner in D-8, besides referring to the emails, presents some details about the content of their personal talk, which was not restricted to information about themselves but also involved talking about the country, as excerpt 4 reveals.

The mention of the emails also appears in D-6. The student comments she had to answer questions about herself that were already addressed in the email sent to her partner:

Table 8. Excerpt 5

\begin{abstract}
Ela me fez perguntas que eu já tinha respondido no meu e-mail de apresentação (...). Depois a conversa fluiu mais ou menos bem, às vezes nós nos esforçávamos para encontrar assuntos e não acho que tenhamos muito em comum
\end{abstract}

(D-6. Original occurrence)
She asked me questions I had already addressed in my introductory email (...). After that, the talk was somewhat ok, sometimes we would try hard to find topics and I don't think we have a lot in common.

(D-6. Translated version)

Source: MulTeC (ARANHA; LOPES, 2019)

In addition, the learner in excerpt 5 presents another insight on what the purpose of iTOS might be when she states she and her partner struggled to find topics and were not successful in finding similar interests. Such a comment suggests that, during iTOS, besides sharing information about themselves, learners should also try to find common ground with their partners. Apart from her, two other students mention such concern (D-5 and D-14):

4 The instructions inform that "Learners write an email (in the target language) in which they introduce themselves to the partner". 
Table 9. Excerpt 6

I haven't learned anything very important in the first interaction because we talked about music, foods, our interests and our families. Basically, we met ourselves and we found that we have interests similars.

Learner in D-5 emphasizes that during iTOS, she and her partner discussed things that interested them ("music, foods, our interests and our families"). Although she considers these topics to be unimportant for learning ("I haven't learned anything very important"), her report indicates that she understands iTOS purpose to be to learn about the partner and discover similar interests.

Despite being less common in learners' reports, the idea that iTOS serves for learners to find common ground relates to researchers' understanding of the communicative purpose of the genre. According to Rampazzo and Aranha (2019b), the purpose is to establish contact and support the partnership, and one way of doing this is learners' effort to find topics to talk about that are interesting to both students in a dyad.

With regards to the research question proposed earlier - What can learners' diaries of iTOS inform us about its communicative purpose? - this study highlights that the first diary sheds light on the purposes of the genre iTOS from the point of view of some of the members of the teletandem community, the learners. The analysis suggests that learners may recognize that the purpose of iTOS is similar to the one intended by the introductory emails, as iTOS gives them a chance to get to know their partners, and it is especially aimed at allowing them to find common ground.

Based on these findings, then, it is possible to conclude that learners' and researchers' stances on the communicative purpose are connected: while the former seems to consider the purpose of iTOS to know their partners and find common ground, the latter's proposition that iTOS occurs so that learners can establish contact is grounded on the idea that contact is instituted through the exchange of personal information.

\section{Final remarks}

This paper aimed at discussing (one of) the communicativepurpose(s) of a telecollaborative genre that occurs in the project Teletandem Brasil (TELLES, 2006), namely the initial teletandem oral session (iTOS) in institutional integrated teletandem (iiTTD) (ARANHA; CAVALARI, 2014). Based on the understanding that genre analysis may help elucidate how members of a community work towards their goals, the study of the communicative purpose of iTOS assists in understanding the patterns of action that are effective in this form of telecollaboration. 
Considering that the teletandem community (TC) is formed by members of different degrees and that it is the members of a community who make use of genres to serve their needs, it is important to investigate all members' viewpoints of what the communicative purpose of a genre is. Through the analysis of the first learning diaries, this paper advances in identifying learners' stance of iTOS communicative purpose and in pointing out that students and researchers have similar positions. The investigation leads to concluding that the communicative purpose of iTOS, as suggested by learners' diaries, is to allow learners to get to know their partners and try to find common ground as they embark on the Teletandem journey together.

Nevertheless, this research is subject to limitations. MulTeC (ARANHA; LOPES, 2019) does not include the learning diaries written by learners from the American university, which would also contribute to the interpretation of the communicative purpose of the genre. In addition, the study could be expanded by adding triangulation, including interviews or questionnaires with all degree members of the teletandem community. Further studies could be dedicated to examining iTOS communicative purpose by: (i) observing learning diaries from other classes and groups; (ii) interviewing all members of the teletandem community and crosschecking the answers.

\section{Acknowledgements}

I thank doctors Solange Aranha and Queila Lopes for organizing and sharing MulTeC, Viviane Klen-Alves for carefully reading earlier drafts of the manuscript, and the anonymous reviewers for their contributions.

\section{REFERENCES}

ARANHA, S. Os gêneros na modalidade de teletandem institucional integrado: a primeira sessão de interação. In: NASCIMENTO, E. L.; ROJO, R. H. R. (org.). Gêneros de texto/discurso e os desafios da contemporaneidade. Campinas: Pontes, 2014. p. 97-117.

ARANHA, S.; BRAGAGNOLLO, R. M. Genres and teletandem: Towards a successful relationship. In: LIMA-LOPES, R. E.; FISCHER, C. R.; GAZOTTI-VALIM, M. A. (org.).

Perspectivas em línguas para fins especificos: Festchrift para Rosinda Ramos. Campinas: Pontes Editores, 2015. p. 81-91.

ARANHA, S.; CAVALARI, S. M. S. A trajetória do projeto Teletandem Brasil: da modalidade Institucional Não-Integrada à Institucional Integrada. The ESPecialist, v. 35, n.2, p. 183-201, 2014. 
ARANHA, S.; LEONE, P. The development of DOTI (Databank of oral teletandem interaction). In: FISHER, D.; BEIBWENGER, M. (org.). Investigating computer-mediated communication corpus-based approaches to language in the digital world. Ljubljana: University Press, Facultry of Arts, p. 172-190, 2017.

ARANHA, S.; LOPES, Q. B. Moving from an internal databank to a sharable multimodal corpus: the MulTeC case. The ESPecialist, v. 40, n.1, n.p, 2019.

ARANHA, S.; WIGHAM, C. R. Virtual exchanges as complex research environments: facing the data management challenge. A case study of Teletandem Brasil. Journal of Virtual Exchange, v. 3, p. 13-38, 2020.

ASKEHAVE, I.; SWALES, J. M. Genre identification and communicative purpose: a problem and a possible solution. Applied Linguistics, v. 22, n. 2, p. 195-212, 2001.

BAZERMAN, C. Constructing experience. Carbondale and Edwardsville: Southern Illinois University Press, 1994.

BHATIA, V. K. Analysing genre: Language Use in Professional Settings. London and New York: Longman, 1993.

BRAMMERTS, $\mathrm{H}$. Tandem language learning via the internet and the International E-Mail Tandem Network. In: LITTLE, D.; BRAMMERTS, H. (ed.). A Guide to Language Learning in Tandem via the Internet. CLCS Occasional Paper, 46. Dublin: Trinity College, 1996. p. 9-21.

BENEDETTI, A. M.; CONSOLO, D. A.; VIEIRA-ABRAHÃO, M. H. (org.). Pesquisas em ensino e aprendizagem no teletandem Brasil: línguas estrangeiras para todos. Campinas: Pontes, 2010. p. 21-45.

CAVALARI, S. M. S.; ARANHA, S. Teletandem: integrating e-learning into the foreign language classroom. Acta Scientiarium: Language and culture, v. 38, n. 4, p. 327-336, 2016.

CURTIS, A.; BAILEY, K. M. Diary Studies. OnCUE Journal, v. 3, n. 1, p. 67-85, 2009.

DOOLY, M.; SADLER, R. "If you don't improve, what's the point?" Investigating the impact of a "flipped" online exchange in teacher education. ReCALL, v. 32, n. 1, p. 4-24, 2020.

HELM, F. Language and culture in an online context: what can learner diaries tell us about intercultural competence? Language and Intercultural Communication, v. 9, n. 2, p. 1-14, 2009. 
LOPES, Q. B. MulTeC: A construção de um corpus multimodal em teletandem. 2019. Tese (Doutorado em Estudos Linguísticos) - Instituto de Biociências, Letras e Ciências Exatas, Universidade Estadual Paulista "Júlio de Mesquita Filho", São José do Rio Preto, 2019.

MILLER, C. R. Gênero como ação social. In: DIONÍSIO, A. P.; HOFFNAGEL, J. C. (org.). Gênero textual, agência e tecnologia. Tradução Judith Chambliss Hoffnagel. São Paulo: Parábola Editorial, 2012. p. 21-41.

RAMPAZZO, L. Gêneros do intercâmbio virtual: recorrência retórica e uso de polidez no primeiro encontro síncrono. 2021. Tese (Doutorado em Estudos Linguísticos) - Instituto de Biociências, Letras e Ciências Exatas, Universidade Estadual Paulista "Júlio de Mesquita Filho", São José do Rio Preto, 2021.

RAMPAZZO, L. Gêneros textuais e telecolaboração: uma investigação da sessão oral de teletandem inicial. 2017. Dissertação (Mestrado em Estudos Linguísticos) - Instituto de Biociências, Letras e Ciências Exatas, Universidade Estadual Paulista "Júlio de Mesquita Filho", São José do Rio Preto, 2017.

RAMPAZZO, L.; ARANHA, S. A sessão oral de teletandem inicial: a estrutura retórica do gênero. DELTA: Documentação e Estudos em Linguística Teórica e Aplicada, v. 34, n.1, p. 449-473, 2018.

RAMPAZZO, L.; ARANHA, S. Revisitar o conceito de comunidade para discutir sua aplicação a contextos telecolaborativos. Alfa: Revista de Linguística (UNESP. Online), v. 63, p. 373-396, 2019a.

RAMPAZZO, L.; ARANHA, S. Telecollaboration and genres: a new perspective to understand language learning. Journal of Virtual Exchange, 2, p. 1-22, $2019 \mathrm{~b}$.

SILVA, J. M. Projeto Teletandem Brasil: as relações entre as comunidades virtuais, as comunidades discursivas e as comunidades de prática. 2012. Dissertação (Mestrado em Estudos Linguísticos) - Instituto de Biociências, Letras e Ciências Exatas, Universidade Estadual Paulista, São José do Rio Preto, 2012.

SILVA, R. F. Um estudo com foco no uso do diário reflexivo como instrumento de promoção da autonomia. 2014. Iniciação Científica (Graduando em Licenciatura em Letras) Instituto de Biociências, Letras e Ciências Exatas, Universidade Estadual Paulista Júlio de Mesquita Filho, Cidade, 2014. 
SWALES, J. M.; JAKOBSEN, H.; KEJSER, C.; KOCH, L.; LYNCH, J.; MØLBAEK, L. A new link in a chain of genres? Hermes, Journal of Linguistics, v. 25, p. 133-141, 2000.

SWALES, J. M. Genre Analysis: English in academic and research settings. Cambridge: Cambridge University Press, 1990.

SWALES, J. M. Other Floors, Other Voices: A Textography of a Small University Building. Mahwah: Lawrence Erlbaum Associates, 1998.

SWALES, J. M. Reflections on the concept of discourse community. ASp, v. 69, p. 7-19, 2016.

SWALES, J. M. Research Genres: Explorations and Applications. Cambridge: Cambridge University Press, 2004.

SWALES, J. M. Worlds of genre - metaphors of genre. In: BAZERMAN, C.; BONINI, A.; FIGUEIREDO, D. (ed.). Genre in a Changing World. Colorado/Indiana: The WAC Clearinghouse and Parlor Press, 2009. p. 1-16.

TELLES, J. A. Projeto Teletandem Brasil: Línguas Estrangeiras para Todos - Ensinando e Aprendendo línguas estrangeiras in-tandem via MSN Messenger. Faculdade de Ciências e Letras de Assis, UNESP, 2006.

TELLES, J. A. Teletandem and Perfomativity. Revista Brasileira de Linguística Aplicada, v. 15, n. 1, p. 1-30, 2015.

TELLES, J. A. (org.). Teletandem: um contexto virtual, autônomo e colaborativo de aprendizagem de línguas estrangeiras para o século XXI. Campinas: Pontes Editores, 2009.

VASSALLO, M. L.; TELLES, J. A. Foreign Language Learning in-tandem: theoretical principles and research perspectives. The ESPecialist, v. 27, n. 1, p. 83-118, 2006. 